\title{
On the Sources of Saul Bellow's Sentiments for Jewish Intellectuals
}

\author{
Zhe Wang ${ }^{1, *}$ \\ ${ }^{1}$ School of Foreign languages, Sichuan University of Arts and Science, Dazhou, Sichuan, China \\ *ldxywz@sina.com
}

\begin{abstract}
This paper explores the sources of Saul Bellow's sentiments for Jewish intellectuals. The author holds that Saul Bellow is not simply an American writer, but is also significantly a Jewish writer, a Jew by birth, Jewish culture, Jewish beliefs, especially high Jewish anxiety and trepidation, which are deeply penetrated into every corner of his monumental works. It is quite safe to say his work is a Jewish history of the second half of the twentieth century in America. If his work is a gift to all Jews, Saul Bellow has been a Jewish gift to all peoples on the planet.
\end{abstract}

Keywords: Saul Bellow, Jewish sentiments, Jewish family, Jewish history, Jewish archetype

\section{INTRODUCTION}

Saul Bellow (1915-2005), a member of the generation of Jewish-American intellectuals, has been hailed as the most important American novelist of the post-war years, being lumped with others (usually Bernard Malamud and Philip Roth) as one-third of a Jewish-American triumvirate. As a Jewish-American writer, Bellow's work offers a penetrating account of the history of the second half of the twentieth century. Bellow once said, "I think a human being has to be faithful to his unique history. If that history is mixed, scrambled, anomalous, difficult for any outsider less exotic to put together for himself, that's not my fault... I was faithful to what I was. I live that way and I tried to write that way" [1].

If you go deep into Bellow's work, you will find almost all the heroes in Bellow's work are Jews, who, at the same time, are intellectuals in America. Whether the hero is Moses Herzog of Herzog (1964), a history professor with a Ph.D., or Charlie Citrine of Humboldt's Gift (1975), an intellectual middle-aged author; whether the hero is Albert Corde of Dean's December (1982), the dean of a Chicago college, or Benn Croder of More Die of Heartbreak (1987), a world-famous botanist, or Abe Ravelstein of Ravelstein (2000), a brilliant thinker, all these heroes are Jewish-Americans living in America, and they all do their best to realize self-surmounting and grow strong unceasingly, but each and every time they are all banking on their wisdom and hard working to survive cities of material prosperity. Saul Bellow constantly creates for readers these so full, vivid, alive and physical protagonists that researchers on him have to transfer their research direction inadvertently toward the source of his sentiments for the Jewish intellectual, in the hope that they can have a better understanding of the implied meanings of these life-like characters and then proceed to grasp the profound thematic ideology in Bellow's work. Now Saul Bellow and some other American-Jewish writers have drawn quite a lot of critical attention and "they are now considered significant figures, representative of their Jewish Origins as well as of American fiction in its totality"[2].

\section{INFLUENCE OF THE JEWISH FAMILY}

According to halakha, if both parents are Jewish, their child will also be considered Jewish; if he or she is Jewish, their Jewishness will be invariable. "One cannot become more Jewish by opting for greater Jewish involvement, and cannot become less Jewish by opting for less. No Jews are more Jewish than other Jews. One does not sacrifice any quotient of Jewishness by marrying a non-Jew, because the identity resides in the self and is independent of the course one's life takes" [3]. For Western culture the Jews has been a symbol of evil, an alien figure unto whom society projected its unconscious fears. Since the Holocaust, Jewish characters have been frequently sentimentalized as paragons of virtue and assigned abstract moral values such as hard work, love of man, integrity and stoical endurance of humiliation. 
Saul Bellow was, in fact, born into a poor, immigrant Yiddish-speaking family in Canada. He was born Solomon Bellows in 1915 in Lachine, Quebec, the fourth child of Russian Jewish parents, Abraham Bellows and Liza Gordon Bellows. He spent his early years in Montreal, one of the poorest places of that city, where his father worked as an onion dealer and part time bootlegger. As a child, he was extremely fond of reading, and learnt Hebrew at the age of four. His mother, Liza, was very religious and was very strict with little Bellow. She hoped that her precocious child could make a difference in the future. But when Bello was seventeen years old, his mother suddenly passed away, which was a bolt from the blue to young Bellow, so he later said, "My life was never the same after my mother died"[4]. It is his mother who is always central to Bellow's adult recollections of that period. His parents had themselves hardly had time to become aware of what it meant to be Canadian, and his early upbringing in the Montreal slums must have contributed a lot to the sense of cultural displacement and the strong desire for social or intellectual conquest that motivates so many of his protagonists, for the life lived there was essentially a continuation of the European experience from which the immigrants had fled. Bellow drew much from this ghetto upbringing that was to feed his writing, for it tempered the somber Jewish spirit of his orthodox religious education with the vernacular energies of Yiddish languages and culture. Later Bellow came to Chicago as his family moved. But in Chicago Bellow couldn't find something more appealing to him than he did at home in Montreal. He once said, "I grow up there and consider myself a Chicagoan out and out"[5]. As he became old, he continued reading the Hebrew scripture and speaking Yiddish. "Jew, Bellow suggested, seem to know something that many other Americans don't: you can't really make yourself over, and so you remain bound to your earliest attachments"[6]. With his unbridgeable family ties, he finished his fine short story The Old System (1968).

Coming from a Jewish family, maintaining the family bloodline, getting Jewish education, absorbing the soul of Jewish culture and understanding the Jewish thinking mode, Saul Bellow derived from Jewish culture and history lots of colorful writing material, which led him to "regarding the Jewish plight as a good metaphor for discussing the whole human condition"[7]. This was indeed the case just as a famous critic John J. Clayton pointed out, "Saul Bellow defense of man has been made in the cultural confluence of two main streams: the Jewish experience and the American experience"[8]. Therefore, it's sufficient to say that Bellow's work is a collision between and an integration of Jewish experiences and American experience, and he himself is truly an American writer as well as a true Jew. In his novel Him With His Foot in His Mouth (1984), such ideas were once again expressed by the mouth of his hero:
I had raised myself by painful efforts from immigrant origins to middle class level but that I avenged myself for the torments and falsifications of my healthy instincts, deformities imposed upon me by this adaption to respectability, the strain of social climbing. ${ }^{[9]}$

\section{INFECTION OF THE JEWISH CULTURE}

Love of learning knowledge, love of debating issues and love of expressing ideas have been deeply into every Jew since they were born into this world which is full of miseries and sufferings. This brilliant tradition passed down from generation to generation is not just from garrulous smart Jewish mothers and grandmothers just like Saul Bellow's mother once did, who expected her child Bellow "to become a Talmudic scholar like everyone else in her family" ${ }^{[10]}$, it is also from the Infection of the Jewish culture and history. In the past, Jews mainly gained their knowledge in the synagogue and yeshivas, but when it came to re-interpretation of the Torah, every Jew must take part in this difficult work, thus culture must be regained in light of this need for innovation and Jewish life began to be focused on learning and interpretation of Jewish texts, and every intellectual was obliged to engage themselves in such activity. On the other hand, in order to decode Hebrew, every Jew was introduced to Judaism courses. The more Hebrew they learned, the more they could really grasp the spirit of what the basic prayers mean, so every Jew has been aware of having challenges with knowledge acquisition, which would lead to their being accepting into the Jewish community. Now, although JewishAmericans like Saul Bellow, are totally immersed into mainstream culture, yet they are still conscious of their alienation to their surroundings where they live in; although they firmly believe that God appointed the Jews to be his chosen people in order to set an example of holiness and ethical behavior to the world, yet they still keep in mind the fact that being learned is a sign of Jewish integrity and morality. Every Jew wants to try their best to get ahead in this competitive world only through their true skill and genuine knowledge.

Yong Bellow attended kheyder, where he learned Hebrew thoroughly and spoke Yiddish. Such multilingual environment exerted a strong influence on young Bellow. Of course we cannot deny the thought of Hebrew or Yiddish influence out of hand without denying his other source studies. Apparently whatever little Solly Bellows saw he turned into a story. His colorful neighbors and their customs and languages fired his lively imagination and obvious narrative gifts. He has a good command of his Yiddish so that he has translated many stories of high quality, and his most impressive feats are the Yiddish translation of T. S. Eliot. "Bellow's language reflects the duality of the East European concept of reality. One dual 
aspect of his style is the interspersing of his English with Yiddish or Hebrew phrases"[11]. There is no doubt that the Yiddish touches every aspect of his life, and it affects his writing style, his theme and his characters. In many respects Bellow's progress has been a matter of integrating Jewish material with the fabric of American literature, of blending the feel for Yiddish prose rhythms. With the 1953 publication of The Adventures of Augie March (1953) and its opening lines "I am an American, Chicago born,"[12] Saul Bellow announced that Jews were now as much a part of American society as anyone else. That same year the translation of Isaac Bashevis Singer's "Gimpel the Fool" into English (by Saul Bellow, no less!) marked the ascendance of a very different strand of Jewish literature in America. With Jewish culture Saul Bellow continues exploring the spiritual world of humanity, discovering and realizing himself as well as pursuing his inner feelings. The voice of one of his characters' Henderson continues to resound in our ears:

A crowd of facts came upon me with accompanying pressure in the chest. Who-who was I? A millionaire wanderer and wayfarer. A brutal and violent man driven into the world. A man who fled his own country, settled by his forefathers. A fellow whose heart said, I want, I want. Who played the violin in despair, seeking the voice of angels. Who had to burst the spirit's sleep, or else...I said to myself, "You must answer the woman, Henderson. She is waiting. But how?" And the process started over again. Once more it was, Who are you? And I had to confess that I didn't know where to begin.[13]

Today in Bellow's work we can feel his deep understanding of Jewish culture, Jewish sensibility, and Jewish history. It is a Yiddish that never went away. Bellow's intimate connection to his Jewish past and present is obvious to all who know his work. Beautiful Yiddish words and expressions, exquisite Yiddish images and conventional Yiddish humor and wisdom permeate his work. Jewish authors have both created a unique Jewish literature and contributed to the national literature of many of the countries in which they live. Though not strictly secular, the Yiddish works of authors like Sholem Aleichem (whose collected works amounted to 28 volumes) and Isaac Bashevis Singer (winner of the 1978 Nobel Prize), form their own canon, focusing on the Jewish experience in both Eastern Europe, and in America. Now in the United States, Jewish writers like Saul Bellow, are considered among the greatest American authors, and incorporate a distinctly secular Jewish view into many of their works.

\section{INHERITANCE OF THE JEWISH ARCHETYPE}

"Literary critics are accustomed to call these recurrent images and symbols archetypes. Archetypes recur throughout literature because they are also pervasive in life" ${ }^{[14]}$.Likewise, these master images and symbols are also the building blocks of the literary imagination by Saul Bellow, and rather than quarrel with his past, Bellow retraces repeatedly the Jewish familiar and social elements that shaped his character and thought, but ironically, these characters written by Bellow are not always the spokesmen for their group and they don't have a sense of patriotism in comparison with their ancestors, and they are just a group of intellectuals who are living a hard life, and "they are all on the run, not from something but towards something, a goal somewhere which will give them what they lack-firm ground under their feet" $^{\prime[15]}$.

In American fiction, the Jew is not a prominent figure until the twentieth century when Jewish writers began examining the economic struggle of the Eastern European Jewish immigrants in a capitalistic society. What absorbed their attention was the painful loss of the shtetl tradition as the immigrant Jews accommodated themselves to American life. We cannot explore the Jewish characters in Saul Bellow's work without looking at Bellow's holding fast to Jewish culture. The rich contents and profound connotations in Bellow's novels are achieved mainly through Bellow's creating various figures and distinct personalities, and these figures are mainly Jewish intellectuals through whose mouths Bellow narrates his pursuit for the happy life and the ideas about the people and the things around him. Growing up in the Jewish family, Bellow are deeply affected and edified by traditional Jewish culture, and such individual and collective unconsciousness hidden in his blood is well reflected in his work, and in the meantime the Jewish archetype related to such unconsciousness is etched on the heroes in his work. "For Bellow it was both a limiting identity and a source of inspiration"[16]. There is sufficient evidence in Bellow's work of this Jewish archetype. Dangling Man (1944), Bellow's first novel, is his most fundamental manifestation of his Jewishness, and the hero Joseph is a Jew, a dangling man who cannot find his position in the world. Although Saul Bellow don't want to be labelled as a Jewish writer, but this novel is heavily filled with the breath of Jewishness; The Victim(1947) is mainly concerned with the Jewish sense of persecution and the Jewish longing for brotherhood; in his prototypical work The Adventures of Augie March(1953), Bellow dramatizes the dilemma of the urban Jewish poor and lower middle class; the characters in Seize the Day(1956) are recognizably New York Jewish types, and it deals with a son who wants love from his cold, unJewish father, and the novel ends at a Jewish funeral with the protagonist weeping for the dead stranger and for himself; and in Herzog (1964) there is the portrayal of a Jewish childhood and an emphasis on Jewish family feeling, and in this novel we find Jews are always living in the crack of another country, the Jews are experiencing the unprecedented loneliness, and they thus form a sort of 
marginal consciousness; in the Dean's December(1982), the hero Albert Corde gave up the profession as a journalist, and later left his positon as a dean, even at the end of the novel, he was still not able to land his ideal job, and he was always looking for his inner peace. Corde's situation is well reflected the vagrancy Jews are suffering and is also Bellow's true portrayal of the sense of Jewishness; even the late short fictions, especially A Silver Dish (1978), are deeply Jewish. In this short novel, Bellow shows us a Jewish world view against a Christian one.

Saul Bellow is the leading figure of Jewish writers since the World War Two. His work focuses on the current living challenges the Jews are facing, emitting the heavy Jewish breath and embodying the modern Jewish living ideas. The deep meaning of the Jewish archetype in Bellow's work lies in the fact that his work takes root in a kind of complex web of emotions which is in the deep of his heart, an attachment to the Jew. Bellow's heroes are all suffering from poverty, injustice and ignorance, but they all find the truth and value in the life in the end, they all are happy to face the life, and find the balance between the inner world and the physical world, and finally get the essence of life.

\section{CONCLUSION}

Jews have been living in America for decades of generations, and modern American society makes them more Americanized and offers them new characteristics, as a result, their work has more American features and can be more accepted by more and more Americans. On the other hand, Jews tend to live in the Jewish ghetto area, where they inherited many common traditions and beliefs, and even if they don't need to strictly observe these Jewish moral precepts, they at least are influenced by Talmud unconsciously to make their living. Thanks to their Jewish family's influence, their Jewish culture's infection, some Jewish-American writers has been producing more work with unique charm and everlasting influence in world literature. Saul Bellow, winner of Nobel Prize in literature, is among these Jews. Although Bellow is regarded and accepted as a Jewish-American writer, yet he is extremely conscious of the fact that they are still new to the country, they are still living in the embarrassing environment---"while his head towers in the heavens and is occupied with deep meditation concerning God and His wonders, he himself lives in a barrel"[17], and also the crisis of identity has still been one of most important issues many Jews Americans have to confront. As a conscious writer, Bellow takes up full responsibility to make unremitting efforts to demonstrate what happened on Jews in America, as a result the awkward situations Jews have encountered in America are vividly exposed in every corner of his famous work. The echoes of one of Bellow's Jewish heroes has still been reverberating in world literature:
Look at me, going everywhere! Why, I am a sort of Columbus of those near-at-hand and believe you can come to them in this immediate terra incognita that spreads out in every gaze. I may well be a flop at this line of endeavor. Columbus too though he was a flop, probably, when they sent him back in chains. Which didn't prove there was no America.[18]

\section{AUTHORS' CONTRIBUTIONS}

Author: Wang Zhe <ldxywz@sina.com> is a professor at School of Foreign Languages of Sichuan University of Arts and Science, Dazhou, China (635000). His research interests cover British and American literature, focusing on Saul Bellow in recent years.

\section{ACKNOWLEDGMENTS}

This thesis is supported by Sichuan Provincial Social Science Planning "Sichuan Universities Foreign Language and Literature Discipline Construction and Development Project" in 2020---Research on the Original Writing of Bellow's Mid-term Works on American Consumer Culture (Project number: SC20WY028); the thesis is also supported by Sichuan Foreign Language and Literature Research Center in 2020---A Study of Jewish Culture in Saul Bellow's Early Works (Project number: SCWY20-16).

\section{REFERENCES}

[1] Weiss, Michael. "Why We Need Saul Bellow Now". From https://www.the dailybeast.com/why-weneed-saul-bellow-now/2015-12-27/2019-0405, Par4.

[2] Vogel, Dan. "Saul Bellows' Vision Beyond Absurdity: Jewishness in Herzog". Tradition, Vol9, Nov.4, Spring 1968, pp.65-79.

[3] Gohen, Steven M \& Eisen, Arnold M. The Jew Within: Self, Family and Community in America. Bloomington, IN: Indiana University Press, 2000: 23.

[4] Atlas, J. Bellow: A Biography. New York: Modern Library, 2002:35.

[5] Kunitz, Stanley. Twentieth Century Authors. New York: H. W. Wilson Company, 1955: 72.

[6] Mikics, David. Bellow's People: How Saul Bellow Made Life into Art. New York: W. W. Norton \&Company, Inc., 2016: 9.

[7] Chang Yaoxin. American Literature: A Course Selected. Tian Jin: Nankai University Press, 2006: 313. 
[8] Clayton, John Jacob. Saul Bellow: In Defense of Man(Second Edition). Bloomington \& London: Indiana University Press, 1979: 30.

[9] Bellow, Saul. Whom With His Foot in His Mouth. New York: The Viking Press, 1984: 9.

[10] Steers, Nina A. "Successor to Faulkner: An Interview with Saul Bellow". In Cronin, Gloria L \& Siegel, Ben (ed.). Conversations with Saul Bellow. Jackson: University Press of Mississippi, 1994: 2836 .

[11] Gitenstein, Barbara. "Saul Bellow and Yiddish Literary Tradition". Studies in American Jewish Literature (1975-1979), Vol. 5, No. 2, pp. 24-46.

[12] Bellow, Saul. The Adventures of Augie March. New York: The Viking Press, 1953: 3, 536.

[13] Bellow, Saul. Henderson, the Rain king. New York: The Viking Press, 1958: 77.

[14] Ryken, Leland. Words of Delight: A Literary Introduction to the Bible. Michigan: Baker Book House, 1987: 26.

[15] Gierow, Karl Ragnar. "Novel Prize in Literature Presentation Speech". $\quad$ From https://www.nobelprize.org/prizes/literature/1976/c eremony-speech/2019-04-13/2019-04-14, Par6.

[16] Wolf, A. Jacob. "Saul Bellow, Jew". Judaism, Vol.50, Issue 2. 241-246.

[17] Wohlfarth, John W. Elysium. Bloomington, IN: 1stBooks, 2001: 195. 